\section{Paliukh 0., Kyrychok P., Dziadyk E.}

\title{
ANALYSIS OF THE INFLUENCE OF BINDING ADHESIVES ON THE STRUCTURAL STRENGTH OF INTEGRAL AND SEMI-RIGID COVERS
}

The object of the research is the processes of adhesion structural parts of integral and semi-rigid covers with bookbinding adhesives using continuous and discrete methods of applying adhesive. The conducted experimental studies are based on the use of a comparative technique for measuring the rigidity of double glued and double without adhesion binding materials by determining objective indicators of destructive pressure. The main assumption of research is that the use of various types of bookbinding adhesives applied in continuous and discrete layers will contribute to the formation of additional structural strength of the produced covers. This can't be achieved without analysis and selection of adhesive polymer compositions from those widely used in bookbinding processes, taking into account the structural strength of the covers acquired after adhesion with these compositions. It is proposed to use fragments of integral and semi-rigid covers, made of high-quality coated papers of various weights, in an amount sufficient to obtain the confidence indicators of the study. As a result of experimental studies of glued coated paper samples, an increase in the relative indicators of structural strength is revealed, caused by the physicochemical effect of various types of adhesives. The features of the application of adhesive polymer compositions on the glued fragments of covers by continuous, tape and checkerboard methods are revealed. Analysis of double glued with a continuous layer of cover fragments, in comparison with double non-glued fragments, showed a significant increase in the relative structural strength of the glued fragments in a wide size range. It is determined that the discrete commensurate deviation of the obtained indicators is caused by the properties used for the research of adhesives. Comparative analysis of glued fragments of covers by tape and checkerboard methods of adhesion application revealed a significant difference in the experimental strength indicators obtained, towards a significant advantage of the checkerboard method. This, in addition to ensuring the structural strength of the glued fragments of the covers, close to the continuous method of applying the adhesion, contributes to a significant reduction in its expenditure component. The results of studies to determine the influence of a sample of binding adhesives, common in the technological processes of manufacturing book products, on the structural strength of integral and semi-rigid covers, to contribute to the planning of resource-saving technological processes.

Keywords: binding adhesive, punching forces, structural strength, integral cover, semi-rigid cover.

Received date: 02.04.2020

Accepted date: 27.05 .2020

Published date: 31.08 .2020
Copyright (c) 2020, Paliukh O., Kyrychok P., Dziadyk E. This is an open access article under the CC BY license (http://creativecommons.org/licenses/by/4.0)

\section{Introduction}

Integral semi-rigid covers constitute a separate group of modern resource-saving book frames, the production of which requires an insignificant amount of binding materials at a significantly lower cost compared to binding [1]. However, it should be noted that the use of a small number of technological processes for the manufacture of such book frames does not limit the wide possibilities in the reproduction of the design and the implementation of finishing processes [2]. And their design features, which consist in the presence of edges or valves obtained in the process of cutting reamers, bent and glued along the contour and planar parts, contribute to operational strength and a long period of use [3]. Accordingly, conditional plates of operational reinforcement are formed along the contour of these covers, as one of the elements of a significant advantage over edged covers [4]. The use of adhesive polymer compositions of various merit, for binding edges and flaps, leads to fluctuations in the mechanical strength, primarily, of the contour part of the covers [5]. This circumstance is due to the fact that in the process of adhesion structural parts to the main part of the covers with adhesive polymer compositions, after folding and rotating pressing, a composite anisotropic structure is formed [6]. The strength of such a structure depends on the high adhesive properties of the used binding materials and the degree of their compression during the production of covers [7]. In works [8,9] it is shown that due to the established dependences of the influence of the fractal structure of paper on the formation of the adhesive layer of the adhesive joint, its strength depends on the 
total area of mutual contact. In addition, the process of the formation of structural strength is determined by the magnitude of the macroroughness of the surface, the number and size of pores and capillaries, and the depth of adhesive penetration into them [10]. During the formation of adhesive joints of binding materials for the manufacture of covers, a highly viscous adhesive mass comes into contact with the surface of the substrate [11]. Due to this, in order to describe the process of the formation of the contact between the adhesive and the substrate, in [12], the important characteristics of the adhesive and the conditions for the formation of the contact are determined. Much attention is paid to the rheological processes occurring at the adhesive-substrate interface associated with the filling of micro surface defects with the adhesive polymer [13].

In particular, it is found [14] that the strength of the adhesive bond to the greatest extent determines the concentration of the polymer in the adhesive solution or in the dispersion; therefore, the adhesive of the highest concentration is used in cases where maximum bond strength is required. A high concentration of dry matter in the adhesion ensures the maximum number of molecular contacts between the adhesive and the substrate, a short setting time and fixing of the adhesive layer, and minimal time and energy consumption for the drying process [15]. Taking into account the properties of the binding materials from which the covers will be made, it is possible to calculate the corresponding dimensions of the edges and flaps, depending on the format of the publication and the thickness of the spine of the book block. In turn, the application of adhesion to the calculated edges and flaps, their screw folding, calendering and final reduction, in the complete polymerization of the connecting adhesion, occurs in the process of high-speed flow movement. This makes it difficult to maintain tight tolerances for deviations from the rectangular geometry of book frames. Thus, there is reason to assert that long-term adhesion efficiency can be achieved provided that adhesive polymer compositions are used, which will increase the operational strength of integral and semi-rigid covers. In this regard, the object of research is the processes of adhesing structural parts of integral and semi-rigid covers with bookbinding adhesives using continuous and discrete methods of applying adhesive. The aim of research is to experimentally determine the influence of a sample of binding adhesives, common in the technological processes of manufacturing book products, on the structural strength of integral and semi-rigid covers.

\section{Methods of research}

Experimental studies to determine the structural strength of integral and semi-rigid covers were carried out on the basis of the use of technology for measuring the rigidity of binding materials, from the determination of objective indicators of destructive pressure [16]. The study is based on the task of using a test device developed by the authors [16], which measures the punching resistance of certain types of binding materials, to determine the pressure indicators at which the studied glued samples are destroyed. Fig. 1 shows a schematic diagram of a test device on which experimental studies of the structural strength of integral and semi-rigid covers were carried out.
The testing device operates as follows. On the lower pressure plate 1 is placed a fragment of the cover under study, consisting of two parts of the cover material 2, 4, connected by an adhesive polymer composition 3 . The upper pressure plate 5 with the help of the clamping device 6 tightly fixes the cover fragment under study. Due to the gradual increase in pressure in the hydraulic device 8, the pushing element 7 moves downward, passes through the first hole in the upper pressure plate and comes into contact with the cover fragment. The punching element continues to move gradually towards the hole in the lower pressure plate, gradually bending and stretching the test specimen. On the verge of losing the structural strength of the cover fragment, further deforming punching forces lead to the destruction of the sample and stop the punching element. The force of destruction is recorded using measuring equipment.

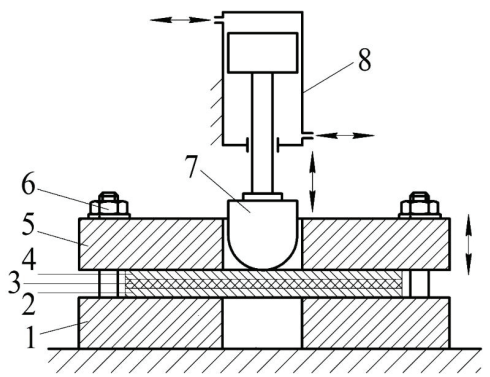

Fig. 1. Test device for determining the punching shear resistance of binding materials: 1 - lower pressure plate; 2, 4 - cover binding material; 3 - adhesive polymer composition; 5 - upper pressure plate; 6 - clamping device; 7 - punching element; 8 - hydraulic pressure device

The production of integral and semi-rigid covers, as innovative structural components of the structural construction of books, involves the use of modern adhesive polymer compositions and economical means of their application [17]. Fig. 2 presents for research three main options for applying adhesive compositions to structural elements of covers:

1 - continuous layer $t(\mathrm{~mm})$ over the entire plane;

2 - discrete tape layer, in which the width of the adhesive tape $t_{1}(\mathrm{~mm})$ is equal to the width of the blank elements $s_{1}(\mathrm{~mm})$ without adhesive;

3 - discrete checkerboard layer, in which the area of the cells with the applied adhesive $S_{a d}=t_{2} \cdot t_{3}\left(\mathrm{~mm}^{2}\right)$ corresponds to the area of the blank elements without adhesive $S_{b l}=s_{2} \cdot s_{3}\left(\mathrm{~mm}^{2}\right)$, that is $S_{a d}=S_{b l}$.
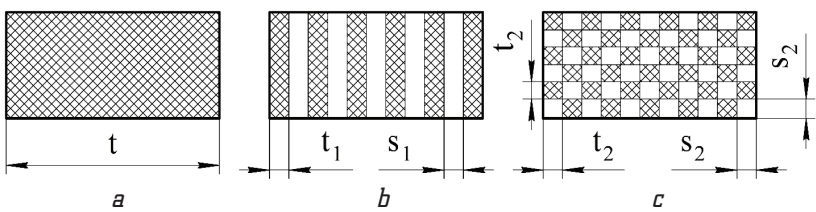

Fig. 2. Schemes for applying adhesive layers on structural elements of integral and semi-rigid covers: $a$ - continuous; $b$ - discrete tape; $c$ - discrete checkerboard

Also, an essential condition for structuring the research is the application of adhesive layers of the same thickness, with deviations, which do not significantly affect the identification of patterns of acquired structural strength of the covers. When mechanized adhesion of structural 
parts of covers made of porous materials with a rough surface (paper, cardboard, binding cover materials), the technologically determined thickness of the adhesive layer is in the range of 60-90 microns. For experimental studies, the applied adhesive layer with a thickness of 90 microns, which is the maximum recommended. The choice of the maximum thickness of the adhesive layer, provided for by the research conditions, provides the necessary and sufficient accuracy in measuring the effect of the binding adhesives on the structural strength of the covers.

\section{Research results and discussion}

For the production of integral and semi-rigid covers, the use of thin cardboard one-sided or double-sided coating (chrome-ersatz) with a thickness of $0.25-0.6 \mathrm{~mm}$ and a weight of $175-420 \mathrm{~g} / \mathrm{m}^{2}$ has become widespread. Thin boards have significant cost advantages over high quality coated papers of identical weight and thickness. The downward cost benefits are in the $25-32 \%$ range. At the same time, from a practical point of view, the use of high quality coated paper for the production of covers remains one of the first places. Considering the small number of types of chrome-ersatz cardboard used in the printing industry, samples of high-quality coated VelArt paper produced by the Stora Enso concern (Finland) weighing 130, 150, 170, 200, $250,300,350,400 \mathrm{~g} / \mathrm{m}^{2}$ were selected for the experiments. The range of binding adhesives used for the experiment consists of water-soluble polymer dispersions: PVAD DF 51|15B (Ukraine), PVAD 53-P (Ukraine), AQUENCE GA 7232 (Germany), PLANATOL Emmevil 960/220 (Germany). In addition, from the range of hot melt adhesives common in the printing industry: PLANATOL HM 8010 (Germany), TECHNOMELT 3183 BG (Germany), ThermoFlex W404 (Finland), Jovatherm 291.30 (Germany), QUICKMELT 2133 (Turkey). The viscosity (ISO 3219) of the listed adhesives, according to Brookfield, ranges: at $160{ }^{\circ} \mathrm{C}$ 1500-3500 mPa.s, at $150{ }^{\circ} \mathrm{C} 5000-7500 \mathrm{mPa} \cdot \mathrm{s}$.

Experimental array of indicators of destructive punching forces of coated paper samples, double non-glued and double glued with solid and discrete adhesive layers, formed to build a graphical dependence using the statistical processing technique. For each measurement, 10 samples of one type of paper were used, glued together with one type of adhesion. The arithmetic means were determined for systematization and graphic clarity, in fixed zones of used papers with a weight of 130,150,170, 200, 250, 300, 350, $400 \mathrm{~g} / \mathrm{m}^{2}$. Taking into account the obvious overload of initial measurements and statistical processing, the initial array of the obtained results is not presented. The production of integral and semi-rigid covers provides for a double structure of the materials used, consisting of the main part of the cover, as well as from the edges and flaps of various planar sizes:

$$
T=2 t_{m},
$$

where $T$ - the cover thickness; $t_{m}$ - the coated paper thickness. In the case of bonding structural elements to the cover:

$$
T=2 t_{m}+t_{a d},
$$

where $t_{a d}$ - the adhesive layer thickness.

For a comparative analysis of the effect of binding adhesives on the structural strength of integral and semi-rigid covers, measurements of the destructive pushing forces of double non-glued samples were first carried out. And then double samples, glued with 9 types (Table 1), the most common adhesives in bookbinding, applied with a continuous layer. The results of experimental studies are listed in Table 1.

Analysis of the results obtained (Table 1), presented in the form of graphical dependencies in Fig. 3, shows the maximum increase in the relative indicators of the structural strength of glued paper samples (TECHNOMELT 3183 BG adhesion) with a mass of 150, 170, 200, 250, $300,400 \mathrm{~g} / \mathrm{m}^{2}$. These paper samples, when applied with TECHNOMELT 3183 BG hot melt adhesion, show an increase in relative structural strength values in accordance with the weight of the paper, $3.34 ; 3.57 ; 3.25 ; 3.77 ; 3.64$ 1.92, compared to non-glued specimens. For paper with a weight of $130 \mathrm{~g} / \mathrm{m}^{2}$, using QUICKMELT 2133 hot melt adhesion, the relative index of structural strength is 2.67 . For $350 \mathrm{~g} / \mathrm{m}^{2}$ paper (ThermoFlex W404 adhesion) - 2.79.

However, it should be noted that for the production of integral and semi-rigid covers, the decisive factor for the selection of optimal technological processes is the use of ergonomic and resource-saving factors in these processes. Thanks to this, it is possible to ensure a significant reduction in the expenditure component of the production of book products.

Indicators of destructive punching forces of coated paper samples glued with a continuous adhesive layer

\begin{tabular}{|c|l|c|c|c|c|c|c|c|c|}
\hline \multirow{2}{*}{ No. } & \multicolumn{7}{|c|}{ Adhesive brand } & \multicolumn{9}{c|}{ Weight of coated paper } \\
\cline { 3 - 12 } & & $130 \mathrm{~g} / \mathrm{m}^{2}$ & $150 \mathrm{~g} / \mathrm{m}^{2}$ & $170 \mathrm{~g} / \mathrm{m}^{2}$ & $200 \mathrm{~g} / \mathrm{m}^{2}$ & $250 \mathrm{~g} / \mathrm{m}^{2}$ & $300 \mathrm{~g} / \mathrm{m}^{2}$ & $350 \mathrm{~g} / \mathrm{m}^{2}$ & $400 \mathrm{~g} / \mathrm{m}^{2}$ \\
\hline- & Without adhesive & 7.4 & 7.0 & 7.33 & 8.67 & 10.2 & 12.3 & 17.8 & 28.0 \\
\hline 1 & PVAD DF 51|15B & 7.33 & 7.87 & 9.9 & 14.4 & 17.0 & 25.0 & 29.3 & 33.3 \\
\hline 2 & PVAD 53-P & 6.82 & 7.26 & 9.2 & 12.9 & 15.8 & 23.6 & 27.1 & 31.56 \\
\hline 3 & ADUENCE GA 7232 & 9.2 & 12.6 & 15.8 & 18.2 & 19.9 & 25.8 & 34.9 & 39.16 \\
\hline 4 & PLANATOL Emmevil 960|220 & 11.6 & 14.4 & 18.6 & 21.4 & 26.7 & 28.9 & 41.2 & 46.4 \\
\hline 5 & PLANATOL HM 8010 & 13.8 & 15.6 & 18.1 & 23.7 & 32.1 & 39.4 & 47.7 & 49.1 \\
\hline 6 & TECHNOMELT 3183 BG & 16.2 & 23.4 & 26.2 & 28.2 & 38.5 & 44.8 & 43.8 & 53.7 \\
\hline 7 & ThermoFlex W404 & 15.0 & 17.15 & 19.75 & 25.95 & 34.3 & 41.1 & 49.7 & 51.4 \\
\hline 8 & Jovatherm 291.30 & 11.42 & 13.41 & 16.1 & 20.68 & 26.0 & 32.4 & 38.8 & 43.5 \\
\hline 9 & QUICKMELT 2133 & 17.1 & 19.3 & 22.4 & 26.8 & 31.2 & 37.1 & 43.8 & 48.8 \\
\hline
\end{tabular}




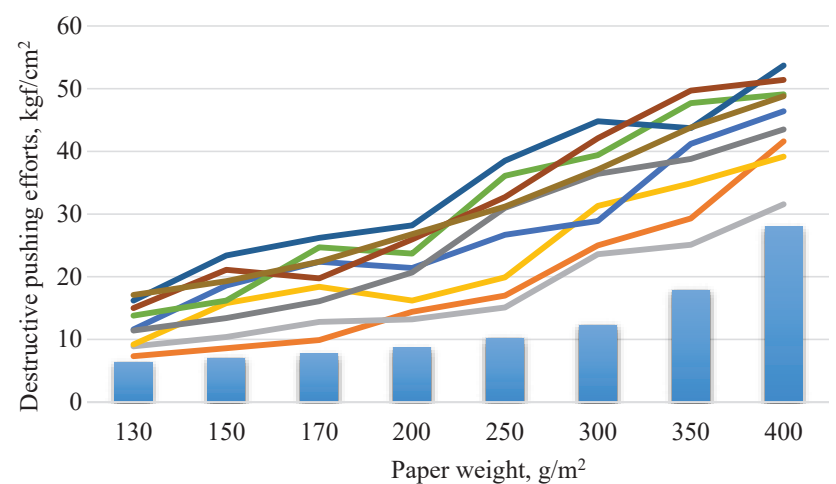

$\begin{array}{lll}\text { Without adhesive } & \text { Row } 1 & \text { Row } 2 \\ \text { Row } 3 & \text { Row } 4 & \text { Row } 5 \\ \text { Row } 6 & \text { Row } 7 & \\ \text { Row } 9 & \text { Row } 8\end{array}$

Fig. 3. Comparative characteristics of the destructive punching forces of glued continuous layer and non-glued coated рарег samples

These technological factors include discrete methods of applying adhesive polymer compositions (tape and checkerboard) for adhesion structural parts of integral and semi-rigid covers. The results of experimental studies of discrete methods of applying adhesion to coated paper samples for making covers are listed in Table 2. Types and weight of papers in Table 2 and in Table 1 are identical.

The use of a discrete tape method of applying adhesion to experimental samples of coated papers revealed the following indicators of the growth of the relative structural strength of the created composite structure. The growth of the maximum relative structural strength (Table 2, Fig. 4), for papers weighing 130, $150 \mathrm{~g} / \mathrm{m}^{2}$ (QUICKMELT 2133 hot melt adhesion), is $1.84 ; 1.88$. For paper $170 \mathrm{~g} / \mathrm{m}^{2}$ (PLANATOL HM 8010 hot melt adhesion) - 2.47. For papers 200, 250, 300, 350, $400 \mathrm{~g} / \mathrm{m}^{2}$ (TECHNOMELT 3183 BG hot melt adhesion) $-2.12 ; 2.29 ; 2.24 ; 1.85 ; 1.46$.
The use of a checkerboard discrete method of applying adhesion, under the circumstances indicated in the previous paragraph, revealed an increase in the maximum relative structural strength (Table 2, Fig. 5), for papers weighing 130, $150,170 \mathrm{~g} / \mathrm{m}^{2}$ (QUICKMELT 2133 hot melt adhesion) - 2, $5,2.59 ; 2.88$. For papers $200,250,300,350,400 \mathrm{~g} / \mathrm{m}^{2}$ (TECHNOMELT 3183 BG hot adhesion) - 3.4; 3.36; 3.3; 2.54; 1.8 .

Experimental studies have revealed the most favorable adhesive polymer compositions using the achieved maximum indicators of structural strength, formed by adhesion composite structures coated paper - adhesion - coated paper. Such adhesives, from those used in experimental studies, were QUICKMELT 2133 (Germany) and TECHNOMELT 3183 BG (Turkey) hot melt adhesives. Fig. 6 shows the relative indicators of the structural strength of glued coated paper samples 130, 150, 170, $200,250,300,350,400 \mathrm{~g} / \mathrm{m}^{2}$. Samples were obtained using continuous, tape and checkerboard methods of applying adhesion.

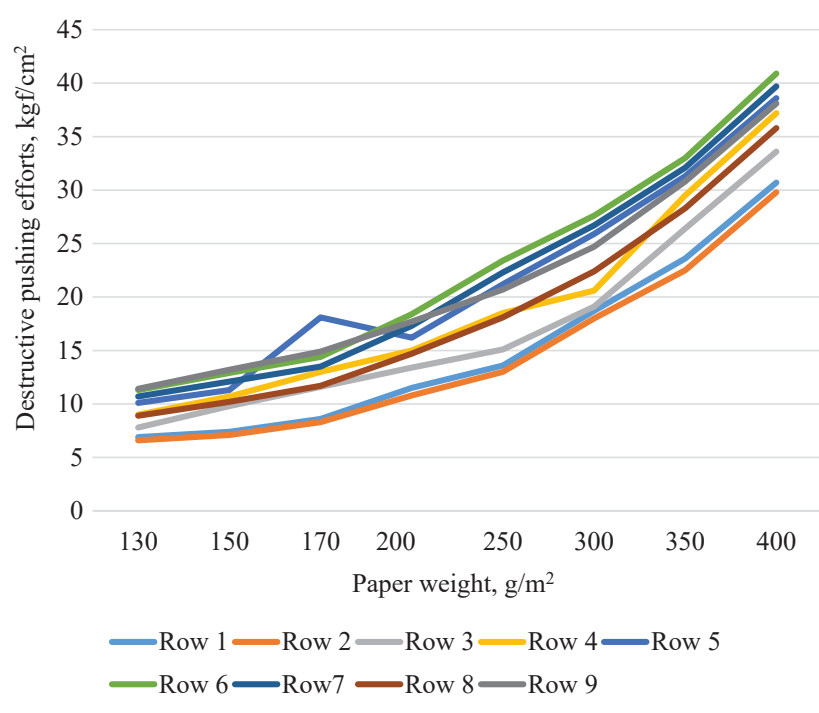

Fig. 4. Comparative characteristics of destructive punching forces of coated paper samples glued with a tape discrete adhesive layer

Table 2

Indicators of destructive punching forces of coated paper samples glued together with discrete adhesive layers

\begin{tabular}{|c|c|c|c|c|c|c|c|c|c|c|}
\hline \multirow{2}{*}{ Weight $\left(g / m^{2}\right)$} & \multirow{2}{*}{ Adhesive layer } & \multicolumn{9}{|c|}{ Adhesive brand } \\
\hline & & 1 & 2 & 3 & 4 & 5 & 6 & 7 & 8 & 9 \\
\hline \multirow{2}{*}{130} & tape & 6.9 & 6.6 & 7.8 & 9.0 & 10.1 & 11.3 & 10.7 & 8.9 & 11.8 \\
\hline & checkerboard & 6.6 & 5.3 & 7.9 & 10.7 & 9.9 & 15.2 & 12.5 & 11.0 & 16.1 \\
\hline \multirow{2}{*}{150} & tape & 7.4 & 7.1 & 9.8 & 10.7 & 11.3 & 12.9 & 12.1 & 10.2 & 13.2 \\
\hline & checkerboard & 7.1 & 7.1 & 10.1 & 13.2 & 11.2 & 17.6 & 14.2 & 12.9 & 18.1 \\
\hline \multirow{2}{*}{170} & tape & 8.6 & 8.3 & 11.6 & 13.0 & 18.1 & 14.4 & 13.5 & 11.7 & 14.9 \\
\hline & checkerboard & 8.9 & 7.2 & 13.6 & 17.1 & 13.0 & 20.1 & 16.4 & 15.5 & 21.1 \\
\hline \multirow{2}{*}{200} & tape & 11.5 & 10.8 & 13.4 & 15.0 & 16.2 & 18.4 & 17.3 & 14.7 & 17.7 \\
\hline & checkerboard & 13.0 & 10.0 & 15.7 & 19.7 & 17.1 & 26.5 & 21.5 & 19.9 & 25.2 \\
\hline \multirow{2}{*}{250} & tape & 13.6 & 13.0 & 15.1 & 18.5 & 21.2 & 23.4 & 22.3 & 18.1 & 20.7 \\
\hline & checkerboard & 15.3 & 12.32 & 17.1 & 24.6 & 23.1 & 34.3 & 28.5 & 25.0 & 29.3 \\
\hline \multirow{2}{*}{300} & tape & 18.7 & 18.0 & 19.1 & 20.6 & 25.9 & 27.6 & 26.7 & 22.4 & 24.7 \\
\hline & checkerboard & 22.5 & 18.4 & 22.2 & 26.6 & 28.4 & 40.2 & 34.1 & 31.1 & 34.9 \\
\hline \multirow{2}{*}{350} & tape & 23.6 & 22.5 & 26.4 & 29.5 & 31.3 & 33.0 & 32.1 & 28.3 & 30.8 \\
\hline & checkerboard & 26.4 & 21.1 & 30.0 & 37.9 & 32.2 & 45.2 & 38.5 & 37.2 & 41.2 \\
\hline \multirow{2}{*}{400} & tape & 30.7 & 29.8 & 33.6 & 37.2 & 38.6 & 40.9 & 39.7 & 35.8 & 38.1 \\
\hline & checkerboard & 30.0 & 24.6 & 33.7 & 42.7 & 35.4 & 50.5 & 42.7 & 41.8 & 45.2 \\
\hline
\end{tabular}


60

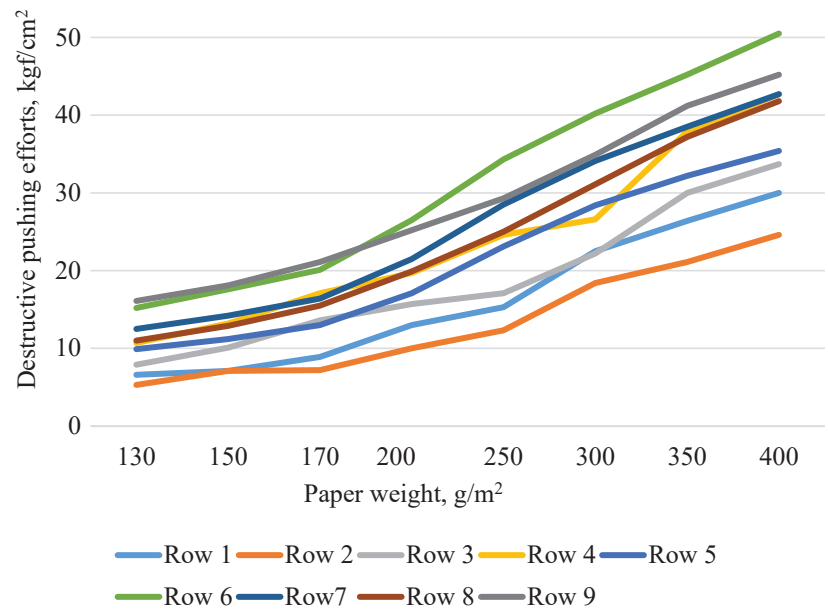

Fig. 5. Comparative characteristics of destructive punching forces of coated рарег samples glued with a checkerboard discrete adhesive layer

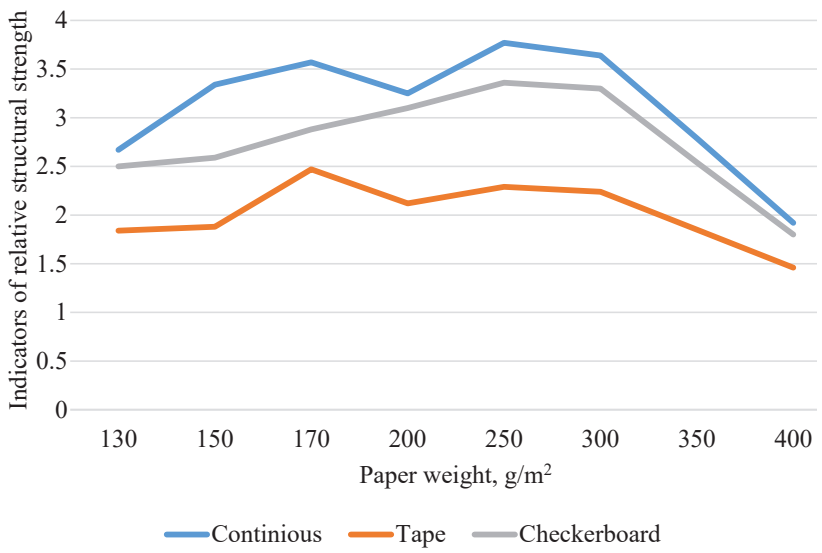

Fig. 6. Comparative indicators of the relative structural strength of glued samples of coated papers using continuous, tape and checkerboard methods of applying adhesion

As seen in Fig. 4, the maximum relative structural strength of glued coated paper samples provides a continuous method of adhesion application, which does not provide a smooth transition between paper samples with a discrete growing weight $\left(\mathrm{g} / \mathrm{m}^{2}\right)$. This requires further studies of changes in the structural strength of glued samples of coated paper of various weights to determine the physicochemical effect of the constituent adhesives. Comparing discrete methods of applying adhesion to coated paper samples, it should be noted that the planar application of adhesion by tape and checkerboard methods is identical to each other in size. But the structural strength is provided to a greater extent by the staggered method of applying the adhesion, which is substantially close in performance to the continuous application of adhesion. In addition, it provides a smooth transition with increasing discrete paper weight in the range of $130-300 \mathrm{~g} / \mathrm{m}^{2}$. The selected range of paper pulp 130 , $150,170,200,250,300 \mathrm{~g} / \mathrm{m}^{2}$ is the most promising for the production of integral and semi-rigid covers. This is facilitated by the obtained experimental relative indicators of the structural strength of the staggered samples and a significant reduction in the consumption of adhesion, approaching $35-45 \%$, in comparison with continuous application.

\section{Conclusions}

As a result of experimental studies of glued coated paper samples of various weights, as fragments of integral and semi-rigid covers, an increase in the relative indicators of structural strength was revealed. The increase in the structural strength of the glued cover fragments is discrete, caused by the physicochemical effect of various types of adhesives common in the printing industry, used for experiments. The features of the application of adhesive polymer compositions on the glued fragments of covers by continuous, tape and checkerboard methods are revealed. Analysis of double glued with a continuous layer of cover fragments in comparison with double non-glued fragments showed an increase in the relative structural strength of the glued fragments in the size range of $1.92 ; 2.67 ; 2.79$; $3.25 ; 3.34 ; 3.57 ; 3.64 ; 3.77$. Discrete deviation of indicators is caused by the physicochemical properties of the adhesives used for research.

Comparative analysis of glued cover fragments by tape and checkerboard methods revealed a significant difference in the obtained experimental indicators of relative structural strength. According to the design conditions, the planar adhesion application in both cases is identical and amounts to 0.5 of the area of structural elements of the glued cover fragments. For the strip method of applying the adhesion, the increase in the relative strength is $1.46 ; 1.84 ; 1.85 ; 1.88 ; 2.11 ; 2.12 ; 2.24 ; 2.29$. At the same time, for the checkerboard method, these indicators are significantly higher and amount to $1.8 ; 2.5 ; 2.54 ; 2.59$; $2.88 ; 3.1 ; 3.3 ; 3.36$. In addition, with the use of discrete application of adhesion on fragments of covers, the consumption of adhesion is significantly reduced, approaching 35-45\%, compared with continuous application.

The research results obtained will contribute to the planning of technological processes for the production of integral and semi-rigid covers, taking into account ergonomics and significant resource saving.

\section{References}

1. Arnett, J. A. (2019). The Art of Bookbinding. Bibliopegia; or The Art of Bookbinding in All Its Branches, 1-8. doi: http:// doi.org/10.4324/9780429030420-1

2. Wilson-Higgins, S. (2018). Trends in book manufacturing on-demand. The Impact of Print-On-Demand on Academic Books, 119-132. doi: http://doi.org/10.1016/b978-0-08-102011-1.00009-2

3. Jerman, P. Reflections on Book Structure-Part 3-Spine Control. Available at: https://www.pinterest.com/pin/194358540139328159/

4. Kornilov, I. K. (2001). Proektirovanie knizhnykh konstrukcii. Moscow: Izd-vo MGUP, 212.

5. Paliukh, O. O. (2017). Eksperymentalne vyznachennia mitsnosti skleienykh zrazkiv paperu i kartonu dlia vyhotovlennia knyzhkovo-zhurnalnykh obkladynok i paliturok riznykh konstruktsii. Tekhnolohiia i tekhnika drukarstva, 4, 11-24.

6. Clark, T. (2007). Bookbinding with adhesives. GRAW-HILL Book Company Europe, 53.

7. Gromyko, I. G., Marchenko, I. V. (2018). Vliianie struktury materialov na formirovanie adgezionnogo shva i kogezionnoi prochnosti kleevogo sloia v koreshke bloka. Trudy BGTU, 4 (1), 14-19.

8. Marchenko, I. V., Dolgova, T. A. (2010). Issledovanie proiavlenii strukturnoi neodnorodnosti bumagi pri pressovanii knizhnykh polufabrikatov i knig. Trudy BGTU. Seriia 4: Print $i$ mediatekhnologii, 31-34.

9. Kulak, M., Piontukh, I., Bobrova, O. (2000). CHto my znaem o bumage: fraktalnaia paradigma. Tekhnologii pererabotki i upakovki, 3 (5), 26-27. 
10. Mishurina, O. A., Mullina, E. R., Chuprova, L. V., Ershova, O. V., Chernyshova, E. P., Permyakov, M. B., Krishan, A. L. (2015) Chemical aspects of hydrophobization technology for secondary cellulose fibers at the obtaining of packaging papers and cardboards. International Journal of Applied Engineering Research, 10 (24), 44812-44814.

11. Mir znanii. Polimery 3. Available at: http://mirznanii.com/a/326348/ polimery-3

12. Mullina, E. R., Ershova, O. V. (2016). Processy adgezii i gidrofobizacii pri proizvodstve gofrokartona. Mezhdunarodnii zhurnal prikladnykh i fundamentalnykh issledovanii, 10 (3), 367-370. Available at: https://applied-research.ru/ru/article/view?id=10350

13. Havenko, S. F. (2012). Kynetyka poshkodzhennia i ruinuvannia kleiovykh ziednan pry ekspluatatsii. Polihrafiia $i$ vydavnycha sprava, 3, 91-96.

14. Vorobev, D. V. (2000). Tekhnolohyia poslepechatnikh protsessov. Moscow: MHUP, 393.

15. Kibirkstis, E., Havenko, S., Gegeckienė, L., Khadzhynova, S. Kadyliak, M. (2019). Influence of Structure and Physical-Mechanical Characteristics of Threads on the Strength of Binding the Books. Mechanics, 25 (4), 313-319. doi: http://doi.org/ 10.5755/j01.mech.25.4.22774
16. Paliukh, O. O. (2019). The Device Design and the Measuring Technique of the Rigidity of Binding Materials for the Manufacture of Integral and Semi-Rigid Covers. Technology and Technique of Typography, 2, 4-14.

17. Paliukh, O. O. (2019). Investigation of the Influence of Discrete Adhesive Application on the Strength of Semi-Rigid BookMagazine Covers. Technology and Technique of Typography, 3, 25-42.

Paliukh Oleksandr, PhD, Associate Professor, Department of Printing Technology, National Technical University of Ukraine «Igor Sikorsky Kyiv Polytechnic Institute», Ukraine, ORCID: http://orcid.org/ 0000-0002-5673-9395, e-mail: alekspalyuh@gmail.com

Kyrychok Petro, Doctor of Technical Sciences, Professor, Director Publishing and Printing Institute, National Technical University of Ukraine «Igor Sikorsky Kyiv Polytechnic Institute», Ukraine, ORCID: http:/ orcid.org/0000-0001-9135-1006,e-mail:petro.kyrychok.kpi@gmail.com

Dziadyk Yevhenii, Postgraduate Student, Department of Printing Technology, National Technical University of Ukraine «Igor Sikorsky Kyiv Polytechnic Institute», Ukraine, ORCID: http://orcid.org/ 0000-0002-6771-7204, e-mail: jdcrow499@gmail.com 